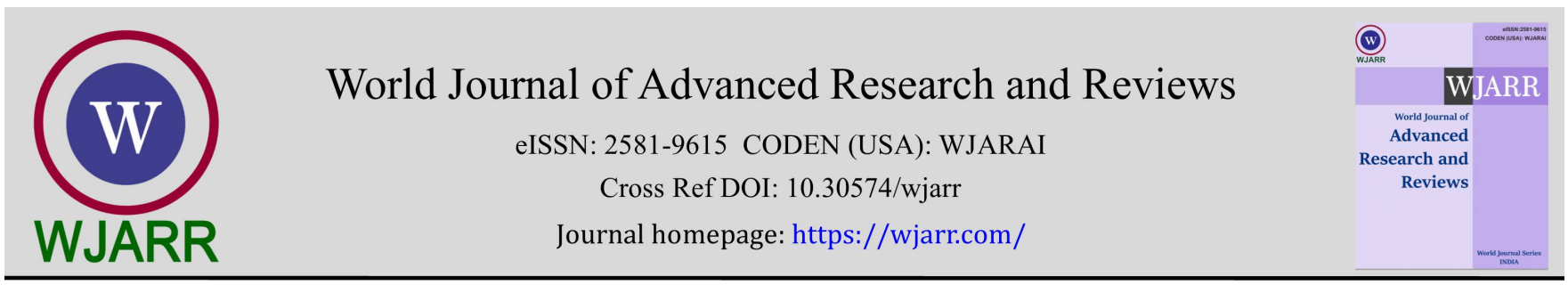

(RESEARCH ARTiClE)

Check for updates

\title{
Growth parameters of Brycinus longipinnis (Günther, 1864) from the Aghien Lagoon (South East of Côte D'ivoire)
}

\author{
Romuald Sonan Assi 1, ${ }^{*}$, Awa Traoré ${ }^{2}$, Martin Kouamé Kouamé ${ }^{1}$, Innocent Allepo Abe ${ }^{3}$ and Mathurin Koffi 3 \\ ${ }^{1}$ Department of Biodiversity and Sustainable Management of Ecosystems, Faculty of Environment, Jean Lorougnon Guédé \\ University, POB 150 Daloa, Côte d'Ivoire. \\ 2 Laboratory for improvement and agricultural production, Faculty of Agroferestry, Jean Lorougnon Guédé University, POB \\ 150 Daloa, Côte d'Ivoire. \\ ${ }^{3}$ Department of Biodiversity and Sustainable Management of Ecosystems, Faculty of Environment, Molecular Genetics and \\ Epidemiology Research Unit, Jean Lorougnon Guédé University, POB 150 Daloa, Côte d'Ivoire.
}

World Journal of Advanced Research and Reviews, 2021, 11(01), 113-119

Publication history: Received on 12 June 2021; revised on 15 July 2021; accepted on 17 July 2021

Article DOI: https://doi.org/10.30574/wjarr.2021.11.1.0324

\begin{abstract}
The growth of Brycinus longipinnis caught at Aghien Lagoon was studied between June 2014 and May 2015 through growth type, condition factor and growth parameters according to the Von Bertalanffy model. Sampling was conducted using experimental fisheries. Growth type was determined from the length-weight relationship and growth parameters according to the Von Bertalanffy model from the FiSAT software. The growth was of negative allometric type $(b=2.59)$. The Brycinus longipinnis population grows faster towards the asymptotic length ( (L $\infty=92.40 \mathrm{~mm}$ SL) with a growth coefficient $K$ of 0.36 year $^{-1}$. It is also a long-lived fish species with maximum longevity $\left(t_{\max }\right)$ of 8.32 years.
\end{abstract}

Keywords: Growth type; Condition factor; Von Bertalanffy growth parameter; Aghien Lagoon; Côte d'Ivoire

\section{Introduction}

Among the lagoons of Côte d'Ivoire, the Aghien lagoon is subject to strong fishing pressure because of its geographical proximity to the large Ivorian agglomeration. Moreover, it appears from the work of Anoh [1] on the comparative strategies for the exploitation of lagoon water bodies in Côte d'Ivoire that the management of the Aghien lagoon is exclusively the business of the traditional chiefs. According to this author, the chieftaincy authorizes access to the resource in exchange for payment of a fee. This authorization does not take into account the quantity and quality of fish. The indigenous populations are therefore not very concerned about finding a balance between the fishing effort and the fish stocks available in the Aghien lagoon [1]. In addition, very little information is available on the fish population of this lagoon. Faced with such a threat, the establishment of a system of management measures is necessary for the preservation of these fishery resources. These measures are based on the knowledge of the growth parameters of the ichthyological species. Indeed, for Coulibaly [2], knowledge of growth parameters has applications in fisheries biology and in the evaluation of fish stocks. The objective of this study is to contribute to the knowledge of the growth parameters of Brycinus longipinnis in the Aghien lagoon for a better management of this fish population. Indeed, it is a pelagic species whose ecological role is very important in maintaining the ecological balance of the Aghien lagoon. In addition, this species is among the abundant and very frequent species in the catches Assi et al [3].

\footnotetext{
${ }^{*}$ Corresponding author: Romuald Sonan Assi

Department of Biodiversity and Sustainable Management of Ecosystems, Faculty of Environment, Jean Lorougnon Guédé University, POB 150 Daloa, Côte d'Ivoire.
} 


\section{Material and methods}

\subsection{Study environment}

The Aghien Lagoon that is the subject of this study is located north of the Ebrié Lagoon between latitudes $5^{\circ} 22^{\prime} \mathrm{N}$ and $5^{\circ} 26^{\prime} \mathrm{N}$ and longitudes $3^{\circ} 49^{\prime} \mathrm{W}$ and $3^{\circ} 55^{\prime} \mathrm{W}$ [4, 5] (Figure 1). This lagoon separated from the rest of the Ebrié Lagoon by the Potou Lagoon covers a watershed of $340 \mathrm{~km}^{2}$. This lagoon covers an area of $19 \mathrm{~km}^{2}$. The Aghien and Potou lagoons communicate through a natural channel.

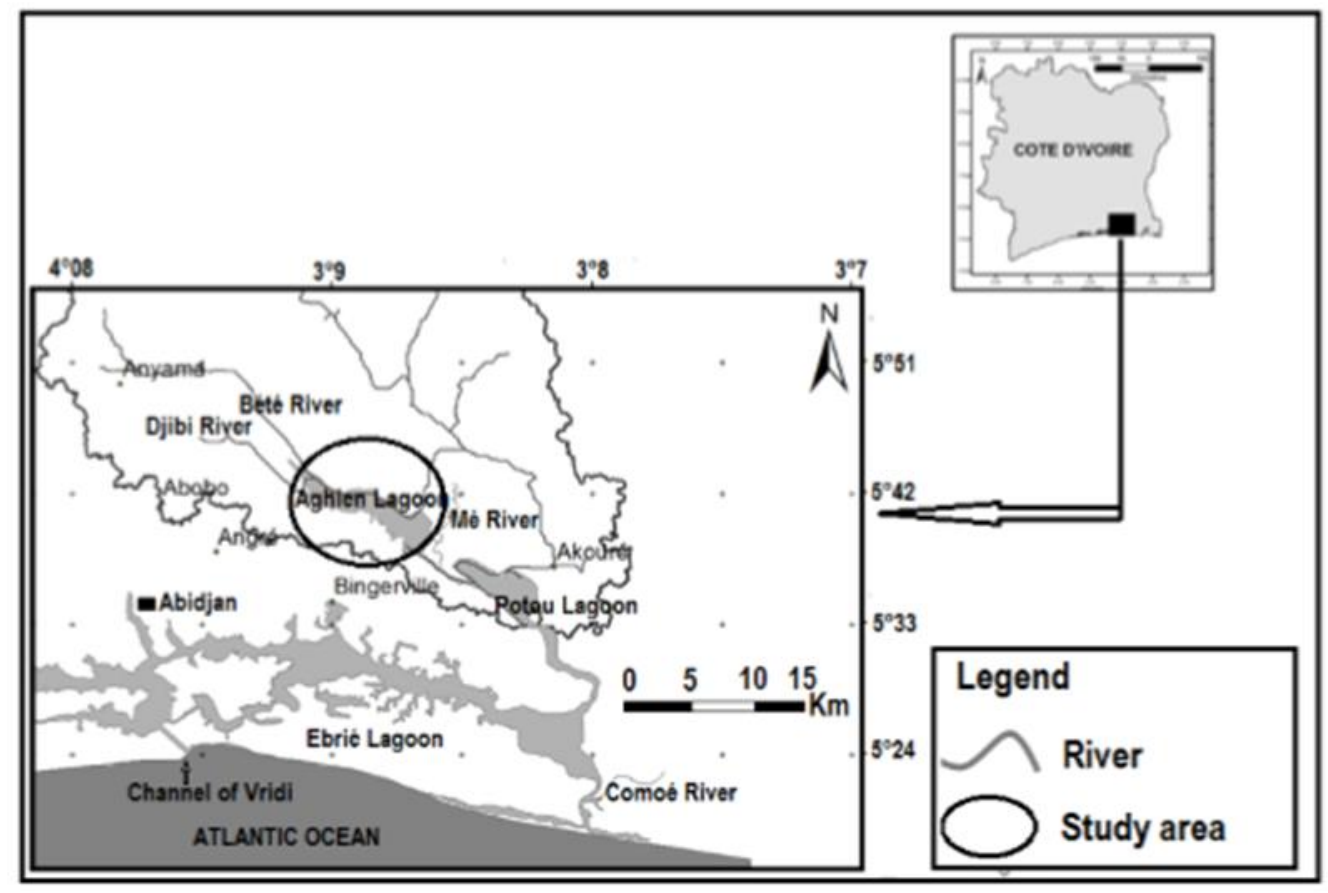

Figure 1 Mapping of the Aghien Lagoon (South-East of Côte d'Ivoire)

\subsection{Data collection and analysis}

Sampling was conducted from the experimental and commercial fishing series ranging from June 2014 to May 2015.

Identification of encountered specimens was performed down to the specific level using keys proposed by [6-10].

On each fish collected, standard length (SL) and weight (W) were measured. The standard length was used during this study because it avoids errors due to accidentally truncated caudal fin [11].

The relationship between weight and length of fish is generally of the exponential type. The length-weight relationship is established according to Lévêque [12] by the following formula:

$$
W=a \times S L^{b}
$$

where $\mathrm{W}$ is the weight of the fish in $\mathrm{g}$; SL, the standard length in $\mathrm{mm}$; $\mathrm{a}$, a constant and b, the allometry coefficient.

The parameter $\mathrm{b}$ was estimated after the transformation of the linear function into a logarithmic function of the type:

$$
\log (W)=\log (a)+b \log (S L)
$$

To determine the type of growth of Brycinus longipinnis (isometric, positive or negative allometry), Student's t-test was used to compare the different coefficients b of the length-weight relationships to the value 3 at the $5 \%$ significance level [13]. Thus, when the value of $b$ is equal to 3 , the growth is said to be isometric. When it is less than 3 , the growth of the fish is negative allometric. When it is greater than 3 , the growth of the fish is said to be positive allometric [14]. 
In order to estimate the overweight status of the individuals of this fish, the condition factor (CF) which provides information on the physical condition of the fish was determined. This index allows the appreciation of the relative weight status of the individuals studied.

For this study, the composite condition factor of Postel [15], which accounts for overweight was used. The expression of the formula is as follows:

$$
C F=\left(W / S L^{b}\right) \times 10^{5}
$$

Where $\mathrm{W}$ is the weight of the fish expressed in $\mathrm{g}$, the standard-length SL in $\mathrm{mm}$ and $\mathrm{b}$ is the allometry coefficient of the length-weight relationship of the fish.

The fish growth parameters were assumed to follow the Von Bertalanffy's growth function (VBGF). Estimates of the Von Bertalanffy growth parameters, the asymptotic length $(\mathrm{L} \infty)$ and the growth coefficient $(\mathrm{K})$ were derived using FiSAT II [16].

Pauly's [17] empirical equation for the theoretical age at length zero $\left(t_{0}\right)$ was used to obtain this parameter as:

$$
\log _{10}\left(-t_{0}\right)=-0.392-0.275 \log _{10} \operatorname{L} \infty-1.038 \log _{10} \mathrm{~K}
$$

The reliability of these growth parameters was tested applying the growth performance index $(\Phi)$ which was computed from the equation [18]:

$$
\Phi^{\prime}=\log K+2 \log L \infty .
$$

Potential longevity, $t_{\max }$, was worked out of the following formula [19]:

$$
t_{\max }=3 / K
$$

\section{Results}

\subsection{Growth type and condition factor}

The equation of the regression curve between weight and standard length as well as the correlation coefficient $(r=0.90)$ of the two parameters (weight and standard length) for the species studied are presented in figure 2.

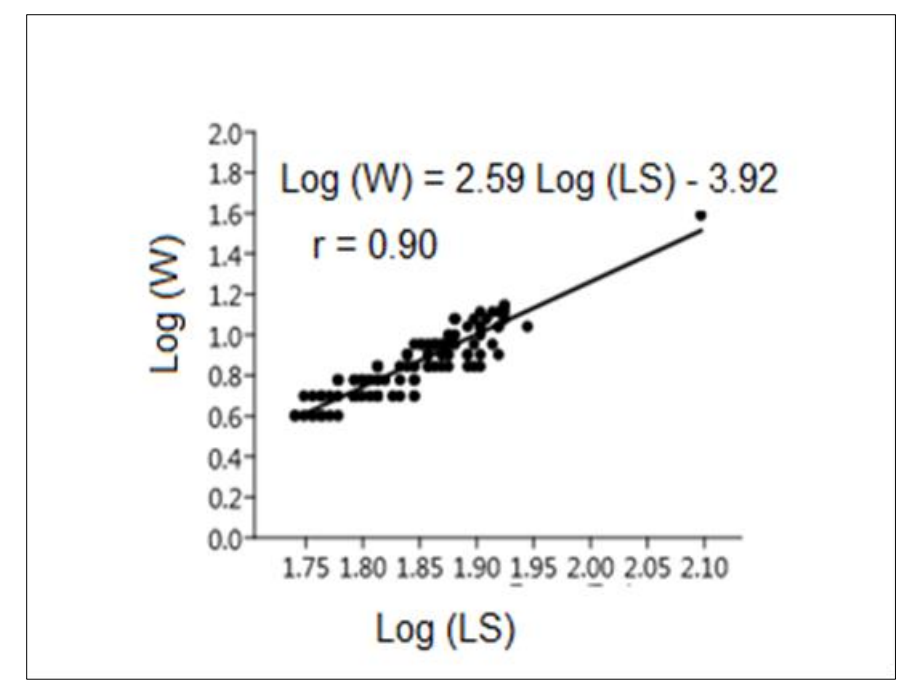

Figure 2 Logarithmic curve of the regression of weight versus standard length of Brycinus longipinnis caught in Aghien lagoon (Côte d'Ivoire) 
This analysis was carried out on 407 individuals of Brycinus longipinnis of standard length between 54 and 90 mm, of which the photograph of a specimen is presented in figure 3.

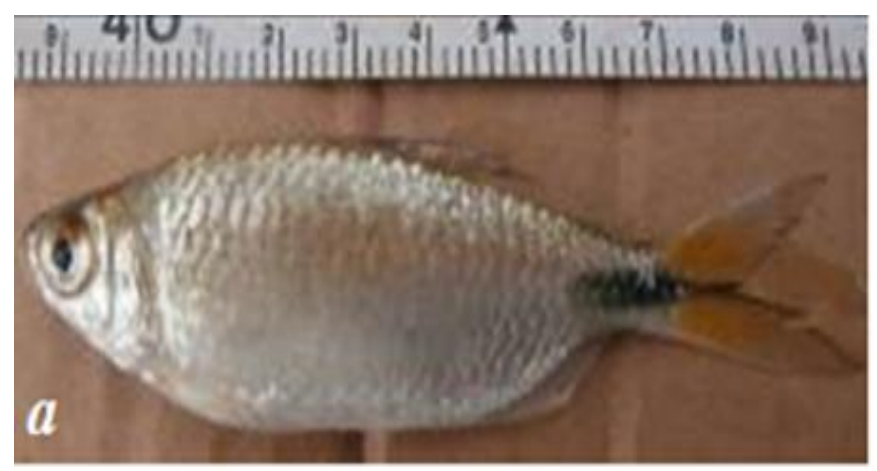

Figure 3 Photograph of a specimen of Brycinus longipinnis captured at the Aghien Lagoon

The estimated value of the allometric coefficient $(b=2.59)$ is statistically lower than the threshold 3 (Student's t-test; $p$ $>0.05$ ). Thus, for individuals of Brycinus longipinnis, the growth is of negative allometric type at the Aghien lagoon.

As for the condition factor of Brycinus longipinnis, it ranged from 0.29 to 3.64 (Figure 4). CF values showed an anomalous distribution (Shapiro-Wilk test $\mathrm{W}=0.97, \mathrm{p}<0.05$ ) with a mean of $1.99 \pm 0.75$. Furthermore, $85 \%$ of the CF values were concentrated around 1 and $15 \%$ of the values were less than 1 .

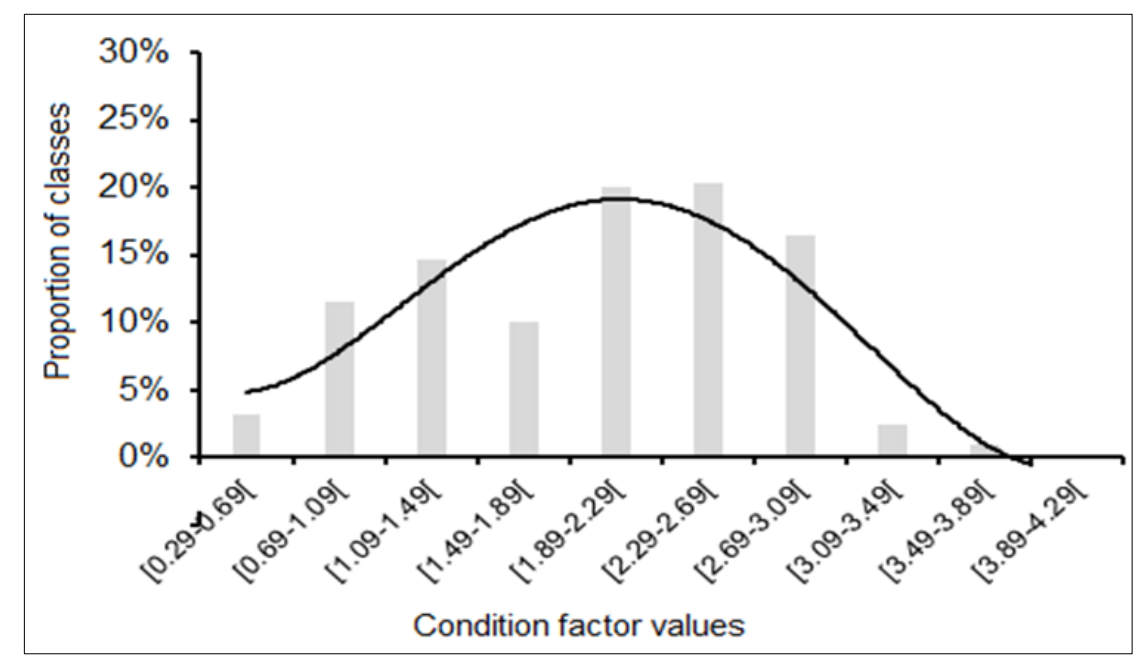

Figure 4 Distribution of condition factor values

\subsection{Growth modeling according to Von Bertalanffy}

The graphical representation of the K-Scan routine and the surface response that enabled the validation of the asymptotic length (Lo), growth coefficient $(\mathrm{K})$, and growth performance index $\left(\Phi^{\prime}\right)$ is shown in figure 5 . Brycinus longipinnis growth parameters estimated from the length frequency distributions are reported in Table 1.

The value of the fit index Rn chosen for the validation of growth parameters was 0.33 . The growth performance index $\left(\Phi^{\prime}\right)$ of Brycinus longipinnis calculated was 1.48 with an asymptotic length (Lo) of $92.40 \mathrm{~mm}$ LS. The rate at which this fish species grows to asymptotic length $(\mathrm{K})$ was 0.36 year $^{-1}$. The longevity, $\left(\mathrm{t}_{\max }\right) 8.32$ years with a theoretical age $\left(\mathrm{t}_{0}\right)$ of -0.62 years.

According to Von Bertalanffy the modelization of the growth of the species Brycinus longipinnis in the Aghien lagoon is as follows:

$$
L t=92,40\left[1-e^{-0,36(t+0,62)}\right]
$$



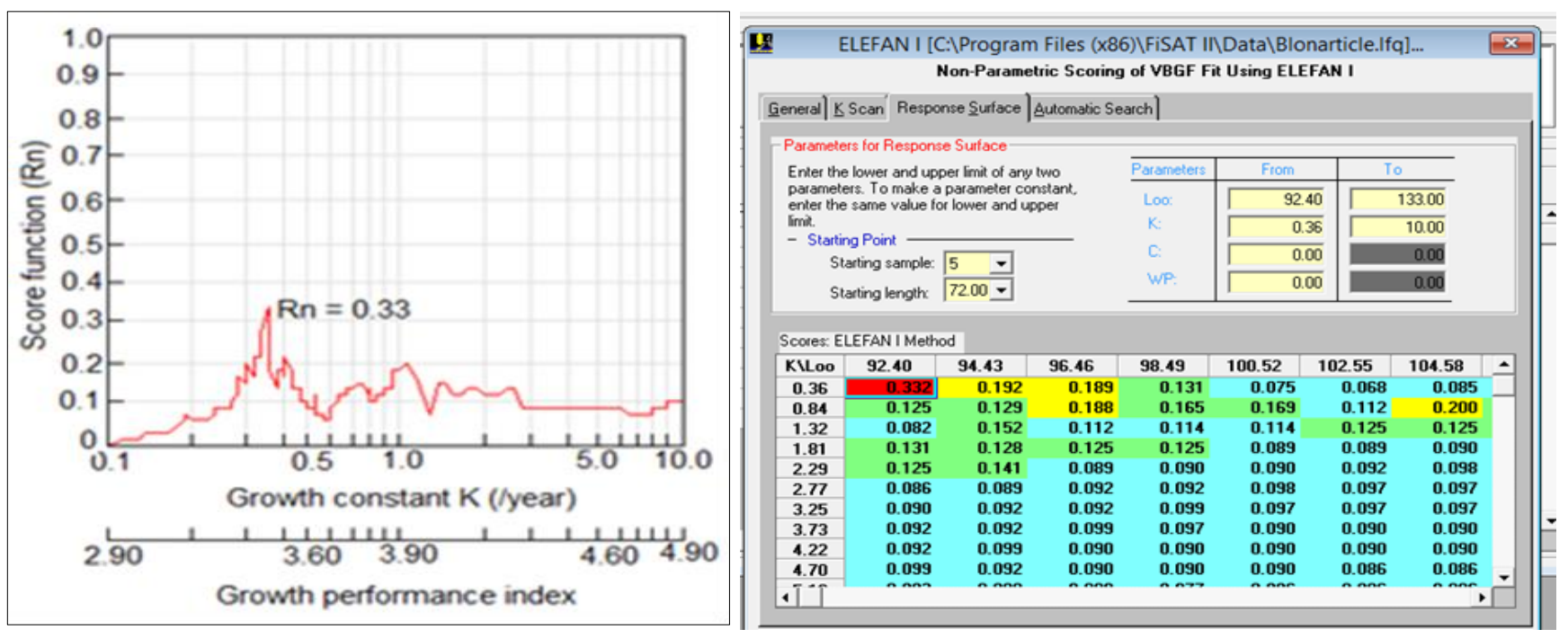

Figure 5 Proof of validation of the asymptotic length and the growth coefficient K from FiSAT software

Table 1 Growth parameters of Brycinus longipinnis caught in the Aghien lagoon (Côte d'Ivoire)

\begin{tabular}{|c|c|c|c|c|c|}
\hline $\begin{array}{l}\text { asymptotic } \\
\text { length }\end{array}$ & $\begin{array}{c}\text { Growth } \\
\text { coefficient }\end{array}$ & $\begin{array}{c}\text { Score } \\
\text { function }\end{array}$ & $\begin{array}{c}\text { Growth } \\
\text { performance index }\end{array}$ & $\begin{array}{l}\text { Potential } \\
\text { longevity }\end{array}$ & $\begin{array}{c}\text { theoretical } \\
\text { age }\end{array}$ \\
\hline $\begin{array}{l}\mathrm{L} \infty=92.40 \\
\mathrm{~mm} \mathrm{LS} \mathrm{mm}\end{array}$ & $\begin{array}{l}\mathrm{K}=0.36 \\
\text { year }^{-1}\end{array}$ & $\mathrm{Rn}=0.33$ & $\Phi^{\prime}=1.48$ & $\begin{array}{l}t_{\max }=8.32 \\
\text { years }\end{array}$ & $\begin{array}{l}\left(\mathrm{t}_{0}=-0.62\right. \\
\text { year }\end{array}$ \\
\hline
\end{tabular}

\section{Discussion}

The study of the population growth of Brycinus longipinnis at Aghien Lagoon revealed that the regression between weight and standard length are highly significant ( $\mathrm{r}=0.90 ; p<0.05)$. This means that the increase in length induces an increase in weight. Thus, the fish grows in length as well as in weight [20]. The preponderance of the growth rate of length over weight or that of weight over length in fish is evaluated by the coefficient b whose value varies from 2 to 4 according to Layachi et al [21]. In this study, the value of the allometry coefficient b of the length-weight relationship obtained $(b=2.59)$ falls within the range of values according to Layachi et al [21]. The analysis of the $b$ coefficient revealed a negative allometric type growth for Brycinus longipinnis. Thus, for this fish species, weight gain is less rapid than length growth.

Our results also shed light on the state of fish welfare in the Aghien Lagoon through the determination of the condition factor. At the time of this study, the Brycinus longipinus population was in good condition. Indeed, $85 \%$ of the CF values were concentrated around 1. Furthermore, Alhassan et al [22] note that a CF coefficient below 1 suggests that the fish is in poor conditions and a coefficient above 1 implies the opposite.

The values of the growth parameters according to the Von Bertalanffy mathematical model determined in the present study are the asymptotic length (Lo), the growth coefficient $(\mathrm{K})$ and the theoretical age at which the fish has zero length (to). For fitting the Von Bertalanffy equation to the size frequencies of the fish population studied in the Aghien Lagoon, the value of Rn obtained was 0.33. This value is within the range of Rn 0 to 1 indicated by Pauly [23]; this shows that the method used fits best and that the estimated parameters are reliable. Analysis of the growth coefficient result $(\mathrm{K}=$ $0.36 \mathrm{yr}-1$ ) reveals that the Brycinus longipinnis population grows faster towards the asymptotic length. Indeed, Branstetter [24] indicates that the range of $\mathrm{K}$ values $\left(0.20-0.50\right.$ year $^{-1}$ and above) is characteristic of fast growing species. Furthermore, the analysis of the growth coefficient $(\mathrm{K})$ indicates that, the species is a long-lived fish species with a maximum lifespan of 8.3 years at Aghien Lagoon. Indeed, according to Jutagate \& De Silva [25], for this coefficient, the interval 0 - 1 year $^{-1}$ is characteristic of long-lived species. 


\section{Conclusion}

At the Aghien lagoon, Brycinus longipinnis has a negative allometric growth pattern. The values of the condition factor reveal that at the time of the study, the population of Brycinus longipinus was in good condition. In addition, B. longipinnis is a fast growing, long-lived fish species.

\section{Compliance with ethical standards}

\section{Acknowledgments}

Data of this study were collected during the project "Study of the water quality of the Aghien Lagoon" and authors are grateful to the promoters of this project: "Agence Française pour le Développement" (AFD) and "Ministère des Eaux et Forêts de Côte d"Ivoire".

\section{Disclosure of conflict of interest}

The authors have not declared any conflict of interests.

\section{References}

[1] Anoh KP. Stratégies comparées de l'exploitation des plans d'eau lagunaire de Côte d'Ivoire. Les Cahiers d'OutreMer. 2010; 251: 347-363.

[2] Coulibaly ND. Relation taille-poids de 11 espèces de poissons du Burkina Faso. In: Fish Biodiversity: Local Studies as Basis for Global Inferences; (ACP-EU). Palomares M. L. D., Samb B., Diouf T., Vakily J. M. \& Pauly D. (eds). Fisheries Research Initiative. 2003; 14: 20-22.

[3] Assi SR, Konan KF, Kouamé KM, Boussou KC, Aliko NG, Gourène G. Diversity and trophic guilds structure of fish assemblages from Aghien Lagoon (Côte d'Ivoire). Aquaculture, Aquarium, Consevation \& Legislation (AACL Bioflux). 2019; 12 (3): 977-988.

[4] Humbert JF. Rapport sur la mission « lagune Aghien ». Rapport d'expertise, AFD-MINEF-SODECI-C2D. 2012; 25.

[5] Traoré A, Soro G, Kouadio KE, Bamba SB, Oga MS, Soro N, Biémi J. Evaluation des paramètres physiques, chimiques et bactériologiques des eaux d'une lagune tropicale en période d'étiage : la lagune Aghien (Côte d'Ivoire). International Journal of Biological and Chemical Sciences. 2012; 6(6): 7048-7058.

[6] Paugy D, Lévêque C, Teugels, GG. Poissons d'eaux douces et saumâtres de l'Afrique de l'Ouest, édition complète. Tome I. Edition IRD-MNHN-MRAC, Paris-Turvuren. 2003a; 457.

[7] Paugy D, Lévêque C, Teugels GG. Poissons d'eaux douces et saumâtres de l'Afrique de l'Ouest, édition complète. Tome II. Edition IRD-MNHN-MRAC, Paris-Turvuren. 2003b; 815.

[8] Sonnenberg R, Busch E. Description of a new genus and two new species of killifish (Cyprinodontiformes: Nothobranchiidae) from West Africa with a discussion of the taxonomic status of Aphyosemion maeseni Poll. 1941. Zootaxa. 2009; 2294: 1-22.

[9] Fricke R, Eschmeyer WN, van der Laan R. (eds). Catalog of fishes: genera, species, references. Version électronique . 2020.

[10] Froese R, Pauly D. (Eds.). FishBase. World Wide Web electronic publication. 2021.

[11] Chikou A. Etude de la démographie et de l'exploitation halieutique de six espèces de poissons-chats (Teleostei, Siluriformes) dans le delta de l'Ouémé au Bénin. Thèse de Doctorat, Université de Liège (Liège, Belgique). 2006; 459.

[12] Lévêque C. Croissance et ontogénie. In: Les poissons des eaux continentales africaines : diversité, écologie, utilisation par l'homme. Lévêque C., Paugy D. (Eds.). Edition IRD, Paris. 2006; 177-190.

[13] Konan KF, Ouattara A, Ouattara M, Gourène G. Weight-length relationship of 57 fish species. Ribarstvo. 2007; 65(2): 49-60.

[14] Morey G, Moranta J, Massuti E, Grau A, Linde M, Riera F, Morales-Nin B. Weight-length relationships of littoral to lower slope fishes from the Western Mediterranean. Fisheries Research. 2003; 62(1): 89-96. 
[15] Postel E. Cours de théorie des pêches (dynamique des populations exploitées). Université de Rennes. 1973; 44.

[16] Gayanilo FCJR, Sparre P, Pauly D. The FAO-ICLARM Stock Assessment Tools II (FiSAT II Version 1.2.2). FAO. 2002.

[17] Pauly D. Theory and management of tropical multispecies stocks: a review with emphasis on the Southeast Asian demersal fisheries. ICLARM Sudies Review. 1979; 1: 35.

[18] Pauly D. Tropical fishes: patterns and propensities. Journal of Fish Biology. 1998; 53: 1-17.

[19] Pauly D. On the interrelationships between natural mortality, growth parameters and mean environmental Temperature in 175 fish stocks. Journal du Conseil International pour l'Exploration de la Mer. 1980; 39(2): 175192.

[20] Ahouansou MS. Diversité et exploitation des poissons de la rivière Pendjari (Bénin, Afrique de l'Ouest). Thèse de doctorat, Faculté des Sciences Agromoniques, Université d'Abomey-Calavi, (Abomey-Calavi, Bénin). 2011; 234.

[21] Layachi M, Melhaoui M, Abdallah S, Ramdani M. Contribution à l'aide de la reproduction et de la croissance du Rouget-barbet de la vase (Mullus barbates L., 1758) de la zone littorale méditerranéenne de Nador (Maroc). Bulletin de l'institut scientifique Rabat section sciences de la terre. 2007; 29: 43-51.

[22] Alhassan EH, Abobi SM, Mensah S, Boti F. The spawning pattern, length weight relationship and condition factor of elephant fish, Mormyrus rume from the Bontanga reservoir, Ghana. International Journal of Fisheries and Aquatic Studies. 2014; 2(2): 109-114.

[23] Pauly D. A review of the ELEFAN system for analysis of length frequency data in fish and aquatic invertebrates. In: Pauly D. \& Morgan R. (Eds.). Length-based methods in fisheries research. ICLARM Conference Proceeding. 1987; $13: 7-34$.

[24] Branstetter S. Age and growth estimates for blacktip, Carcharhinus limbatus, and spinner, C. brevipinna, sharks from the Northwestern Gulf of Mexico. Copeia. 1987; 4: 964 - 974.

[25] Jutagate T, De Silva SS. Yield, growth and mortality rate of the Thai river sprat, Clupeichthys aesarnensis, in Sirinthorn Reservoir, Thailand. Fisheries Management and Ecology. 2003; 2(10): 221-231. 